УДК 658:330.131

DOI: https://doi.org/10.37320/2415-3583/7.7

\begin{abstract}
Міщук Є.B.
кандидат економічних наук, доцент, доцент кафедри обліку, оподаткування, публічного управління та адміністрування, Криворізький національний університет ORCID: https://orcid.org/0000-0003-4145-3711
\end{abstract}

\title{
МЕТОДОЛОГІЯ ОЦІНЮВАННЯ РІВНЯ БЕЗПЕКИ ЕКОНОМІКО-ВИРОБНИЧИХ ІНТЕРЕСІВ ПІДПРИЕМСТВА
}

У статті виявлено, ще підхід до очінювання рівня безпеки економіко-виробничих інтересів підприємства, який би базувався на визначенні одного однозначного показника для всіх ї̈ складників, залишився недостатньо розробленим. Визначено, щзо як такий показник доцільно оцінювати величину нестачі прибутку до оподаткування (EBT), яку підприємство отримує в разі недосягнення монопоказниками складників безпеки своӥх заздалегідь фіксованих значень. Запропонований кониептуальний підхід передбачає прямий рахунок $і$ досить прозоре інтегрування отриманих сум нестач ЕВТ за всіма підвидами иієї безпеки, розтамованими на різних рівнях ї̈ ієрархї за методом найгіриого варіанта: оиінювання кожного наступного підвиду безпеки, розташованого на більш високому щаблі ієрархії безпеки економіко-виробничих інтересів, передбачає вибір максимальної величини нестачі ЕВТ. Це робить підхід ефективним інструментом під час планування заходів щчодо забезпечення економіковиробничої безпеки підприємства.

Ключові слова: безпека енергетичних інтересів, безпека матеріало-сировинних інтересів, безпека технікотехнологічних інтересів, прибуток.

Постановка проблеми. 3 оціночно-аналітичної точки зору економічна безпека підприємства $\epsilon$ багаторівневим ієрархічним показником. Одним із найважливіших його складників є безпека економіко-виробничих інтересів, що також є кількома рівнями ієрархї̈ відповідних підвидів безпеки. Особливістю оцінювання таких складників, яка притаманна більшості сучасних методик, є те, що однозначні й більш-менш загальновживані індикатори (або, як ми ще їх називаємо, монопоказники) притаманні тільки тим видам безпеки, які розташовані на найнижчому рівні iєрархії. Початковою найуживанішою сферою їх використання був економічний аналіз, а однією 3 ключових задач - виявлення внутрігосподарських резервів. 3 розвитком безпекології сфера застосування цих індикаторів розширилась. Водночас інші види безпеки, які розташовуються на більш високих щаблях у загальній ієрархії, не мають класичних, загальновизнаних індикаторів. Наприклад, загальновідомий показник фондовіддачі використовується для оцінювання ефективності використання основних засобів i, в принципі, дає змогу зробити більш-менш виважений висновок. Проте для оцінювання безпеки техніко-технологічних інтересів підприємства його одного вже не достатньо. Для вирішення цієї проблеми безпекознавцями розроблено дуже широкий відповідний інструментарій. У зв'язку 3 цим сучасна безпекологія налічує величезний масив комплексних та інтегральних показників, регресійних моделей тощо. Таке позитивне прагнення науковців, як намагання врахувати якомога більше чинників і монопоказників під час розроблення моделей оцінювання окремих складників безпеки, привело до того, що ці моделі (комплексні показники тощо) стали громіздкими, подекуди перевантаженими другорядною інформацією, складними у математичному підрахунку й такими, для оцінювання яких потрібні великі обсяги специфічної інформації управлінського обліку та, відповідно, часу. Отже, на практиці вони не знайшли широкого застосування. Зазначене обумовлює необхідність удосконалення методології оцінювання безпеки економіко-виробничих інтересів підприємства.

Аналіз останніх досліджень і публікацій. Найбільш вдалою, на наш погляд, є методика О.В. Нусінової та О.В. Молодецької [1; 2], які для оцінювання всіх видів економічної безпеки підприємства запропонували визначати суму прибутку, яку підприємство недоотримує внаслідок того, що ті чи інші індикатори не відповідають своїм нормативним значенням. Окремо відзначимо, що нами розглянуто некоректність застосування терміна «нормативне», у зв'язку з чим запропоновано вживання поняття «лімінальна величина». Повертаючись до змісту вказаної методики, відзначимо, що науковцями застосовуються такі види прибутку, як операційний та прибуток до вирахування витрат за відсотками, сплати податків та амортизаційних відрахувань $[1 ; 2]$. Однак у наших попередніх дослідженнях ми обгрунтували, що замість них доцільнішим видається прибуток до оподаткування. Крім цього, у структурі економічної безпеки підприємства 
авторів праць $[1 ; 2]$ не враховано окремі складники безпеки економіко-виробничих інтересів, що, відповідно, впливало на результати оцінювання загального рівня цього виду безпеки. Слід також зазначити вагомість теоретичних і практичних надбань у галузі економічної безпекології, які зробили Ю.Б. Кашубіна [3], В.Г. Алькема, І.В. Больботенко [4], В.Я. Нусінов, К.О. Астаф'єва [5], О.В. Корецька [6], Б.С. Дуб [7], С.А. Івченко [8], Е.І. Данілова [9], Т.О. Меліхова [10], а також низка інших як вітчизняних, так і зарубіжних науковців. Проте підхід до оцінювання безпеки економіко-виробничих інтересів підприємства, який би базувався на визначенні одного однозначного показника для всіх іiі складників, інформація про величину якого була відомою в будь-який час та не потребувала складних математичних обрахунків, залишився недостатньо розробленим.

Мета статті полягає в удосконаленні методології оцінювання безпеки економіко-виробничих інтересів підприємства.

Виклад основного матеріалу. Безпека економіко-виробничих інтересів підприємства, на наш погляд, включає безпеку техніко-технологічних інтересів, безпеку енергетичних інтересів та безпеку його матеріало-сировинних інтересів. Методологія оцінювання рівня кожного складника базується, як вище зазначено, на визначенні нестачі ЕВT.

Розглянемо спочатку оцінку рівня безпеки техніко-технологічних інтересів, яку ми розділили на безпеку майнового стану та безпеку рентабельності основних засобів. Очевидно, що досягнення високого рівня економічної безпеки підприємства неможливе без використання передових технологій. Водночас передовість характеризується конкретним періодом часу, в межах якого певний рівень техніки відповідає відповідній технології. Так, колись прогресивним був і паровий двигун. Отже, лімінальні значення показників, що характеризують їх відповідність сучасному рівню розвитку техніки, доцільно визначати для кожного конкретного періоду часу.

Індикаторами безпеки майнового стану вважаємо загальновживані економістами коефіцієнти оновлення, придатності, фондовіддачі, а також використання основних засобів. Спочатку визначаємо нестачу показника ЕВТ для досягнення лімінального значення коефіцієнтом оновлення основних засобів. Для цього оцінюємо лімінальне значення первісної вартості основних засобів, що введені в експлуатацію у період оцінювання ( БАвпл ):

$$
\text { FАвпл }=\mathrm{L}(\text { Кон }) \times \text { FАкпф, }
$$

де L(Конл) - лімінальне значення коефіцієнта оновлення, в ролі якого використовуємо його середньогалузеве значення у період оцінювання, частки од.; FАкпф - фактична величина основних засобів (fixed assets), визначена за первісної вартості на кінець періоду оцінювання, грн.

Надалі необхідно порівняти отримане лімінальне значення та фактичну величину первісної вартості введених основних засобів (ГАвпф). Коли FАвпл > FАвпф, доцільно визначати нестачу первісної вартості введених основних засобів ( $\triangle$ FАвп ), яка розраховується з виразу:

$$
\triangle \mathrm{FАв \Pi}=\text { FАвпл }- \text { FАвпф . }
$$

Отже, якщо $\Delta \mathrm{FAвп}>0$, робиться висновок про нестачу величини первісної вартості введених основних засобів і необхідність здійснення відповідних капітальних вкладень. У зв'язку з цим нестачу показника EBT доцільно скоригувати на норму амортизаційних відрахувань (Nda) та коефіцієнт ефективності капітальних вкладень (NEкв), на чому також наголошувалося в роботах [5, c. $40 ; 11$, с. 151], тому:

$$
\Delta \mathrm{EBT}(\text { Кон })=(\Delta \text { FАвп } \times \text { Nda } \times \text { NЕкв })-\text { ЕВТф },(3)
$$

де $\Delta \mathrm{EBT}($ Кон) - нестача ЕВТ за коефіцієнтом оновлення, грн.; $\triangle$ FАвп - нестача величини первісної вартості введених основних засобів, грн.

$\mathrm{He}$ менш важливим індикатором $є$ коефіцієнт придатності основних засобів. Математично перетворивши його загальновідому формулу та врахувавши в ній лімінальне значення цього коефіцієнта на рівні середньогалузевого, визначимо лімінальну величину первісної вартості основних засобів. Остання є сумою, за якої коефіцієнт придатності дорівнюватиме середньогалузевому значенню (ГАперл):

$$
\text { FАперл }=\frac{\mathbf{F A з} ф}{\mathbf{L}(\text { Кпр) }}
$$

де FАзф - фактична сума залишкової вартості основних засобів, грн.; L(Кпр) - лімінальне значення коефіцієнта придатності, роль якого відіграє його середньогалузеве значення в період оцінювання, частки од.

Коли лімінальне значення первісної вартості основних засобів (ЕАперл) перевищує ії фактичну суму (FАперф), тобто коли FАперл > FАперф, робиться висновок про нестачу первісної вартості основних засобів за коефіцієнтом придатності ( $\triangle$ FАпер ), яка розраховується з виразу:

$$
\Delta \text { FАпер }=\text { FАперл }- \text { FАперф . }
$$

Аналогічно до попередніх міркувань під час оцінювання нестачі показника ЕВТ слід провести відповідні коригування [5, с. 40; 11, с. 151], у зв'язку з цим:

$$
\Delta \mathrm{EBT}(\text { Кпр })=(\Delta \mathrm{FAпер} \times(\mathrm{Nda}+\mathrm{NЕкв}))-\mathrm{EBT} \phi,(6)
$$

де $\Delta \mathrm{EBT}($ Кпр) - нестача ЕВТ за коефіцієнтом придатності, грн. 
Наступним важливим індикатором є фондовіддача. Для здійснення відповідних математичних перетворень обсяг виробництва розглядається на рівні фактичного (Vф), а як лімінальне значення фондовіддачі використовується іiі середньогалузеве значення в період оцінювання, з урахуванням чого отримаємо лімінальну величину первісної вартості основних засобів за фондовіддачею:

$$
\text { FАrпл }=\frac{\mathbf{V} \phi}{\mathbf{L}(\mathbf{R f a})},
$$

де FArпл - лімінальна величина первісної вартості основних засобів, визначена за показником фондовіддачі, грн.; L(Rfa) - лімінальна величина фондовіддачі (return on fixed assets), частки од.

Подібними до вищенаведених є формули, що передують безпосередньому оцінюванню нестачі величини ЕВТ за показником фондовіддачі $(\Delta \mathrm{EBT}(\mathrm{Rfa}))$ :

$$
\Delta \mathrm{FArn}=\mathrm{FArnл}-\mathrm{FAпер \phi},
$$

$$
\Delta \mathrm{EBT}(\mathrm{Rfa})=(\Delta \mathrm{FAr} \times(\mathrm{Nda}+\mathrm{NE \kappa в}))-\mathrm{EBT} \phi,
$$

де $\Delta$ FArл - нестача величини первісної вартості основних засобів за показником фондовіддачі, грн.; FArпл - лімінальна величина первісної вартості основних засобів, визначена за показником фондовіддачі, грн.; FАперф - фактична сума первісної вартості основних засобів, грн.; $\Delta \mathrm{EBT}(\mathrm{Rfa})$ - нестача величини EBT за показником фондовіддачі, грн.

Для визначення нестачі величини ЕВТ загалом по безпеці майнового стану доцільно серед оцінених сум нестач вибрати найбільше:

$$
\begin{gathered}
\Delta \mathrm{EBT}(\text { БМС })=\max \{\Delta \mathrm{EBT}(\text { Кон }) ; \\
\Delta \text { ЕВТ(Кпр); } \Delta \mathrm{EBT}(\mathrm{Rfa})\},
\end{gathered}
$$

де $\triangle \mathrm{EBT}($ БМС) - нестача суми ЕВТ по безпеці майнового стану підприємства, грн.

Слід відзначити, що іноді величину нестачі показника ЕВТ необхідно зменшувати на суму прибутку, отриманого від основних засобів, які $\epsilon$ недіючими та не використовуються в діяльності підприємства, але які можна реалізувати:

$$
\begin{gathered}
\Delta \mathrm{EBT}(\text { БМС })=\max \{\Delta \mathrm{EBT}(\text { Кон }) ; \Delta \mathrm{EBT}(\text { Кпр }) ; \\
\Delta \mathrm{EBT}(\mathrm{Rfa})\}-\mathrm{EBT}(\text { Квик }),
\end{gathered}
$$

де ЕВТ(Квик) - сума ЕВТ, отримана за рахунок реалізації основних засобів, що не використовуються підприємством, грн.

Проте нині така ситуація більше стосується підприємств суднобудування.

Для визначення безпеки рентабельності основних засобів пропонуємо як індикатор використовувати відповідний коефіцієнт. За допомогою елементарних математичних перетворень отримаємо ту величину первісної вартості основних засобів на кінець періоду оцінювання, сума якої задоволь- нить умову рівності рентабельності основних засобів іï середньогалузевому значенню:

$$
\text { FАпкл }=2 \times \frac{\mathbf{N P}}{\mathbf{L}(\mathbf{R})}-\text { FАпп, }
$$

де FАпкл - лімінальна величина первісної вартості основних засобів на кінець періоду оцінювання, визначена за показником рентабельності основних засобів, грн.; NP - чистий прибуток підприємства (net profit), грн.; L(R) - лімінальна величина рентабельності основних засобів, що прийнята на рівні середньогалузевого значення у період оцінювання, частки од.; FАпп - первісна вартість основних засобів на початок періоду, грн.

Коли лімінальне значення первісної вартості основних засобів на кінець періоду оцінювання, визначене за показником рентабельності основних засобів (FАпкл), перевищує іï фактичну суму (FАперф), тобто коли FАпкл > FАперф, робиться висновок про нестачу первісної вартості основних засобів за коефіцієнтом придатності ( $\triangle$ FАпк $)$ :

$$
\Delta \text { FАпк }=\text { FАпкл }- \text { FАпер } \phi .
$$

Як уже нами зазначалося вище, під час оцінювання нестачі показника ЕВТ слід провести відповідні коригування [5, с. 40; 11, с. 151], пов'язані 3 урахуванням норми амортизації та ефективності капіталовкладень. Однак окрім цього, через те, що для оцінювання лімінальної величини первісної вартості основних засобів на кінець періоду використовувався чистий прибуток, додатково до зазначених коригувань доцільно врахувати ставку оподаткування (Tr):

$$
\begin{aligned}
\Delta \mathrm{EBT}(\mathrm{R})=((\Delta \mathrm{FAпк} \times(1-\mathrm{Tr})) \times \\
\times(\mathrm{Nda}+\mathrm{NE \kappa в}))-\mathrm{EBT} \phi,
\end{aligned}
$$

де $\Delta \mathrm{EBT}(\mathrm{R})$ - нестача показника $\mathrm{EBT}$ за показником рентабельності основних засобів, грн.

Оскільки для оцінювання безпеки рентабельності основних засобів було вибрано один індикатор, то нестача показника EBT, оцінена за його допомогою, $є$ нестачею ЕВТ за цим підвидом безпеки:

$$
\Delta \mathrm{EBT}(\mathrm{R})=\Delta \mathrm{EBT}\left(\mathrm{b}_{\mathrm{R}}\right),
$$

де $\Delta \mathrm{EBT}\left(\mathrm{Б}_{\mathrm{R}}\right)$ - нестача суми ЕВТ по безпеці рентабельності основних засобів підприємства, грн.

Далі розглянемо індикатори складників безпеки енергетичних інтересів підприємства. Оскільки важливим напрямом підвищення цього виду безпеки є зниження енергомісткості продукції, то цей показник вибрано як індикатор такого складника, як безпека енергоефективності. Сума енерговитрат, величина якої задовольнить умову рівності коефіцієнту енергомісткості продукції його середньогалузевому значенню (ЕСеіл), 
визначається шляхом математичного перетворення формули цього коефіцієнта:

$$
\text { ЕСеіл }=\mathrm{L}(\mathrm{Ei}) \times \mathrm{V} \phi,
$$

де L(Ei) - лімінальна величина енергомісткості продукції (energy intensity), якою є іiі середньогалузеве значення в період оцінювання, частки од.; Vф - фактичний обсяг випуску продукції, грн.

Надалі необхідно порівняти отримане лімінальне значення та фактичну величину енергетичних витрат підприємства (ЕСф). Коли ЕСл $<$ ЕСф, доцільно визначати величину перевитрачання енергетичних витрат ( $\triangle \mathrm{EC} \mathrm{Ci})$, яка розраховується з виразу:

$$
\Delta \mathrm{ECei}=\mathrm{EC} \phi-\text { ЕСеіл },
$$

де $\triangle \mathrm{ECei} \mathrm{-} \mathrm{перевитрачання} \mathrm{енергетичних}$ витрат, визначене на основі енергомісткості продукції, грн.

Для подальшого оцінювання необхідно відзначити, що енергетичні витрати є частиною умовнозмінних витрат підприємства, а тому величина їх зміни (за умови сталості суми виручки від реалізації продукції, товарів, робіт, послуг під час оцінювання) дорівнює зміні величини маржинального доходу [5, с. 41; 11, с. 152], що за фіксованої суми умовно-постійних витрат відповідатиме величині нестачі прибутку ЕВТ. На рис. 1 відображено узагальнену схему визначення нестачі ЕВТ під час перевитрачання енерговитрат.

Окремої уваги потребує такий індикатор, як частка енергетичних витрат у собівартості про-

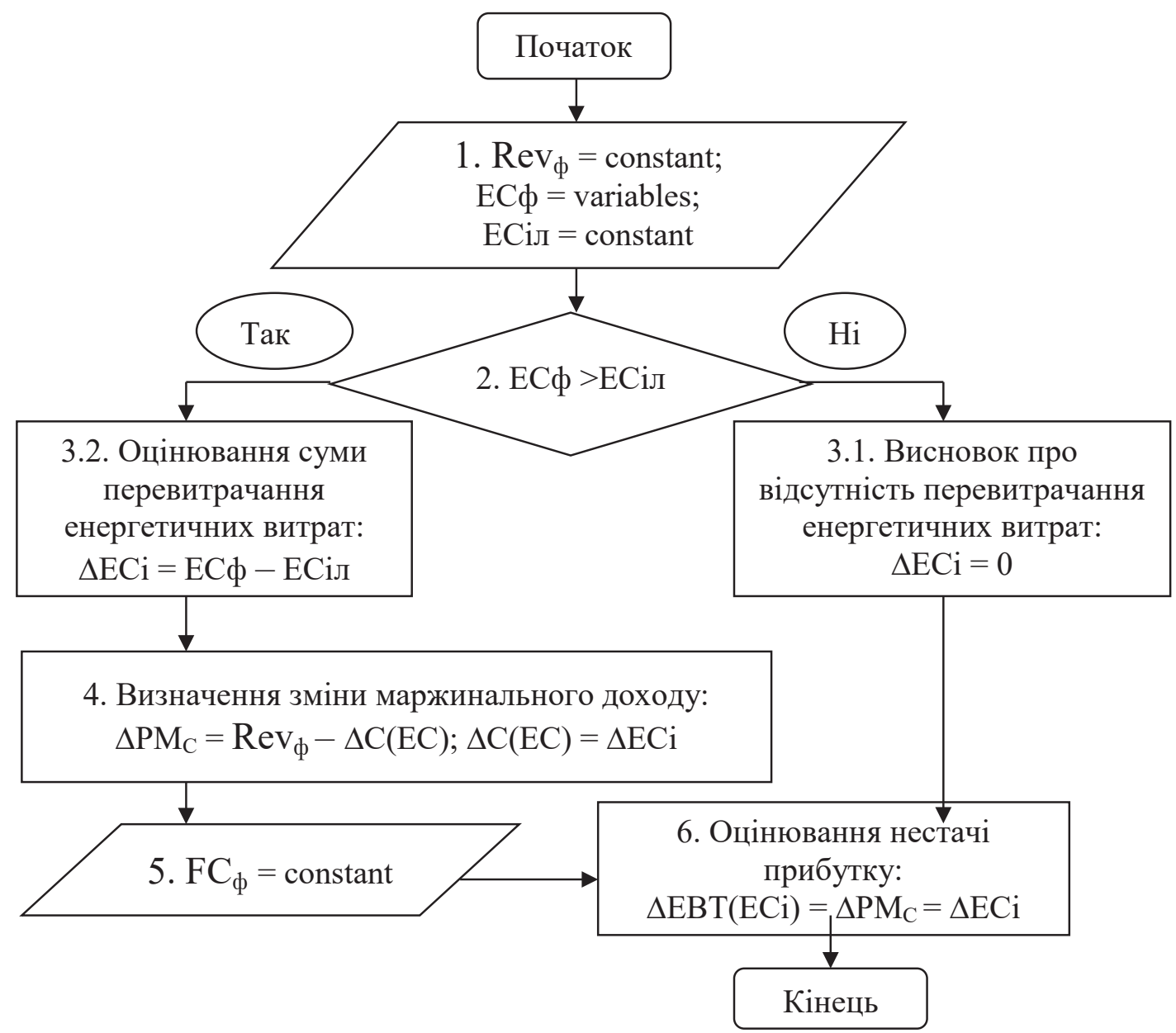

\section{Позначення:}

Рисунок 1 - Блок-схема визначення нестачі показника ЕВТ за умов перевитрачання енергетичних витрат

$\operatorname{Rev}_{\phi}$ - фактична виручка від реалізації продукції (товарів, робіт, послуг) (revenue), грн.; ЕСіл - лімінальна величина енергетичних витрат, визначена за і-м індикатором, грн.; $\Delta \mathrm{PM}_{\mathrm{C}}$ - зміна маржинального доходу (рrofit margins) за рахунок відхилення у сумі умовно-змінних витрат, грн.; $\Delta \mathrm{ECi}-$ перевитрачання енергетичних витрат, оцінене за і-м індикатором, грн.; $\Delta \mathrm{C}(\mathrm{EC})$ - зміна суми змінних витрат за рахунок перевитрачання енергетичних витрат, грн.; $\mathrm{FC}_{\phi}$ - фактична сума постійних витрат (fixed costs), грн.; $\Delta \mathrm{EBT}(\mathrm{ECi})$ - нестача показника ЕВТ за умов перевитрачання енергетичних витрат за і-м індикатором, грн. 
дукції. Узявши як лімінальну питому вагу енерговитрат середньогалузеве значення в період оцінювання (ЕСdесл), отримаємо:

$$
\mathrm{ECdecл}=\mathrm{L}(\mathrm{dec}) \times \mathrm{C} \phi,
$$

де $\mathrm{L}(\mathrm{dec})$ - лімінальна величина частки енерговитрат у собівартості продукції, якою є іï середньогалузеве значення в період оцінювання, частки од.; Сф - фактична собівартість продукції, грн.

Сума перевитрачання енергетичних витрат, визначена за їх часткою у собівартості продукції $(\triangle \mathrm{ECd})$, визначається з виразу:

$$
\Delta \mathrm{ECdec}=\mathrm{EC} \phi-\text { ЕСdесл } .
$$

Далі нестача показника ЕВТ за цією часткою $(\triangle \mathrm{EBT}(\mathrm{ECdec}))$ за умов перевитрачання енергетичних витрат визначається за схемою, наведеною на рис. 1, тобто:

$$
\Delta \mathrm{EBT}(\mathrm{ECdec})=\Delta \mathrm{ECdec} .
$$

Загальна нестача показника ЕВТ за безпекою енергоефективності ( $\triangle \mathrm{EBT}(Б Е н Е))$ визначається таким чином:

$$
\begin{gathered}
\Delta \mathrm{EBT}(\mathrm{BEHE})=\max \{\Delta \mathrm{EBT}(\mathrm{ECei}) ; \\
\Delta \mathrm{EBT}(\mathrm{ECdec})\},
\end{gathered}
$$

де $\triangle \mathrm{EBT}(\mathrm{ECei})$ - нестача показника ЕВТ за коефіцієнтом енергомісткості продукції, грн.; $\triangle \mathrm{EBT}(\mathrm{ECdec})$ - нестача ЕВT за часткою енергетичних витрат у собівартості продукції, грн.

Індикатором безпеки енергозабезпеченості $\epsilon$ коефіцієнт відповідності фактичних обсягів поставок енергоресурсів у грошовому вираженні обсягам, заявленим в укладених договорах (Ker):

$$
\text { Ker }=\frac{\mathbf{E R} \phi}{\mathbf{E R д о г ~}}
$$

де ERф - фактична сума постачання енергоресурсів, грн.; ЕRдог - сума поставок енергоресурсів згідно з укладеними договорами, грн.

Очевидно, що його лімінальне значення має дорівнювати одиниці:

$$
\mathrm{L}(\mathrm{Ker})=1 \text {, }
$$

де $\mathrm{L}(\mathrm{Ker})$ - лімінальне значення коефіцієнта відповідності фактичних обсягів поставок енергоресурсів обсягам, заявленим в укладених договорах, частки од.

При цьому ситуація, коли фактичні поставки енергоресурсів перевищували б їх суми, встановлені в договорах між підприємством та постачальником цих енергоресурсів, тобто Ker $>1$, є практично неможливою, отже, надалі нами не розглядається.

Нестачу показника ЕВТ за безпекою енергозабезпеченості ( $\triangle \mathrm{EBT(БЕн3))} \mathrm{пропонується} \mathrm{нами}$ оцінювати за формулою:

$$
\begin{gathered}
\Delta \text { ЕВТ }(\text { БЕн3 })=\text { ЕВТ } \phi-\text { Ker } \phi \times \\
\times \text { ЕВT } \phi=\text { ЕВТ } \phi \times(1-\text { Ker } \phi),
\end{gathered}
$$

де Kerф - фактичний коефіцієнт відповідності фактичних обсягів поставок енергоресурсів обсягам, заявленим в укладених договорах у період оцінювання, частки од.

Далі розглянемо індикатори складників безпеки матеріало-сировинних інтересів підприємства. Важливими напрямами підвищення цього виду безпеки є зниження матеріаломісткості продукції, а також зниження частки матеріальних витрат у собівартості продукції, тому індикаторами такого складника, як безпека ефективності використання матеріало-сировинних ресурсів, вибрано матеріаломісткість продукції та показник питомої ваги (частки) матеріальних витрат у собівартості продукції. Сума матеріальних витрат, величина якої задовольнить умову рівності коефіцієнта матеріаломісткості продукції його середньогалузевому значенню (МСтіл), визначається шляхом математичного перетворення формули цього коефіцієнта:

$$
\text { MCmiл }=\mathrm{L}(\mathrm{Mi}) \times \mathrm{V} \phi,
$$

де L(Mi) - лімінальна величина матеріаломісткості продукції (material intensity), якою є іiі середньогалузеве значення в період оцінювання, частки од.; Vф - фактичний обсяг випуску продукції, грн.

Надалі необхідно порівняти отримане лімінальне значення й фактичну величину матеріальних витрат підприємства (МСф). Коли МСл < МСф, доцільно визначати величину перевитрачання матеріальних витрат ( $\triangle \mathrm{MCmi})$, яка розраховується з виразу:

$$
\Delta \mathrm{MCmi}=\mathrm{MC} \phi-\text { МСmiл },
$$

де $\triangle \mathrm{MCmi}$ - перевитрачання матеріальних витрат, визначене на основі матеріаломісткості продукції, грн.

Для подальшого оцінювання необхідно відзначити, що матеріальні витрати, як енергетичні витрати підприємства, є частиною його умовнозмінних витрат, тому величина їх зміни також відповідає зміні величини маржинального доходу $[5$, с. $41 ; 11$, с. 152]. У зв’ язку з цим оцінка нестачі показника ЕВТ через перевитрачання матеріальних витрат визначається аналогічно до нестачі EBT, визначеної під час перевитрачання енергетичних витрат (рис. 1). Окремої уваги потребує такий індикатор, як частка матеріальних витрат у собівартості продукції. Узявши як лімінальну питому вагу матеріальних витрат їх середньогалузеве значення у період оцінювання, отримаємо відповідну лімінальну величину матеріальних витрат:

$$
\text { МСdmсл }=\mathrm{L}(\mathrm{dmc}) \times \mathrm{C} \phi,
$$


де МCdmсл - лімінальна величина матеріальних витрат (material costs), визначена за їх часткою у собівартості продукції, грн.; L(dmc) лімінальна величина частки матеріальних витрат у собівартості продукції, якою $є$ її середньогалузеве значення у період оцінювання, частки од.; Сф - фактична собівартість продукції, грн.

Сума перевитрачання матеріальних витрат, визначена за їх часткою у собівартості продукції ( $\triangle \mathrm{MCdmc})$, визначається з виразу:

$$
\Delta \mathrm{MCdmc}=\mathrm{MC} \phi-\mathrm{MCdmcл} .
$$

Далі нестача показника ЕВТ за цією часткою $(\triangle \mathrm{EBT}(\mathrm{MCdmc}))$ за умов перевитрачання матеріальних витрат визначається за схемою, наведеною на рис. 1, тобто:

$$
\Delta \mathrm{EBT}(\mathrm{MCdmc})=\Delta \mathrm{MCdmc} .
$$

Додаткової уваги заслуговує такий індикатор, як рентабельність матеріальних витрат. У іiі чисельнику залежно від цілей дослідження можуть бути застосовані різні показники фінансових результатів, але в межах роботи найбільш доцільним є показник ЕВТ, тому, оцінивши лімінальне значення рентабельності матеріальних витрат як середньогалузеве в період оцінювання, можемо визначити відповідне лімінальне значення показника ЕВТ за фіксованої сумі матеріальних витрат (ЕВT(Rmc)л):

$$
\operatorname{EBT}(\mathrm{Rmc}) \pi=\mathrm{L}(\mathrm{Rmc}) \times \mathrm{MC} \text {, }
$$

де $\mathrm{L}(\mathrm{Rmc})$ - лімінальне значення рентабельності матеріальних витрат, прийняте як середньогалузеве в період оцінювання, частки од.; МСф фактична сума матеріальних витрат, грн.

Якщо отримане значення ЕВТ(Rmc)л > EBTф, то доцільно визначити нестачу ЕВТ, оцінену за рентабельністю матеріальних витрат:

$$
\Delta \mathrm{EBT}(\mathrm{Rmc})=\mathrm{EBT}(\mathrm{Rmc}) л-\mathrm{EBT} \phi,
$$

де $\Delta \mathrm{EBT}(\mathrm{Rmc})$ - нестача показника $\mathrm{EBT}$, оцінена за рентабельністю матеріальних витрат, грн.; EBTф - фактична сума показника ЕВТ, грн.

Загальна нестача показника ЕВТ за безпекою ефективності використання матеріало-сировинних ресурсів визначається таким чином:

$$
\begin{gathered}
\Delta \mathrm{EBT}(\text { БЕвМСР })=\max \{\Delta \mathrm{EBT}(\mathrm{MCmi}) ; \\
\Delta \mathrm{EBT}(\mathrm{MCdmc}) ; \Delta \mathrm{EBT}(\mathrm{Rmc})\},
\end{gathered}
$$

де $\triangle$ ЕВТ(БЕвМСР) - нестача суми ЕВТ по безпеці ефективності використання матеріалосировинних ресурсів підприємства, грн.; $\triangle \mathrm{EBT}(\mathrm{MCmi})$ - нестача показника ЕВT за коефіцієнтом матеріаломісткості продукції, грн.; $\Delta \mathrm{EBT}(\mathrm{MCdmc})$ - нестача показника ЕВТ за часткою матеріальних витрат у собівартості продукції, грн.

Одним 3 індикаторів безпеки матеріало-сировинного забезпечення підприємства є коефіцієнт відповідності фактичних обсягів поставок матеріало-сировинних ресурсів у грошовому вираженні обсягам, заявленим в укладених договорах:

$$
\mathrm{Kmr}=\frac{\text { MR } \phi}{\text { MRдог }},
$$

де $\mathrm{Kmr}$ - коефіцієнт відповідності фактичних обсягів поставок матеріало-сировинних ресурсів обсягам, заявленим в укладених договорах, частки од.; MRф - фактична сума поставок матеріало-сировинних ресурсів, грн.; МRдог - сума поставок матеріало-сировинних ресурсів згідно 3 укладеними договорами, грн.

Лімінальне значення цього коефіцієнта має дорівнювати одиниці:

$$
\mathrm{L}(\mathrm{Kmr})=1,
$$

де $\mathrm{L}(\mathrm{Kmr})$ - лімінальне значення коефіцієнта відповідності фактичних обсягів поставок матеріало-сировинних ресурсів обсягам, заявленим в укладених договорах, частки од.

При цьому ситуація, коли фактичні поставки матеріальних ресурсів перевищували б ї суми, встановлені в договорах між підприємством та постачальником таких ресурсів, тобто $\mathrm{Kmr}>1$, є малоймовірною, отже, надалі нами не розглядається. Нестачу показника ЕВТ за коефіцієнтом відповідності фактичних обсягів поставок матеріало-сировинних ресурсів у грошовому вираженні обсягам, заявленим в укладених договорах $(\Delta \mathrm{EBT}(\mathrm{Kmr}))$, пропонується нами оцінювати за формулою:

$$
\begin{gathered}
\Delta \mathrm{EBT}(\mathrm{Kmr})=\operatorname{EBT} \phi-\mathrm{Kmr} \phi \times \mathrm{EBT} \phi= \\
=\operatorname{EBT} \phi \times(1-\mathrm{Kmr}),
\end{gathered}
$$

де Kmrф - фактичний коефіцієнт відповідності фактичних обсягів поставок матеріало-сировинних ресурсів обсягам, заявленим в укладених договорах у період оцінювання, частки од.

На особливу увагу також заслуговує ще один індикатор безпеки матеріало-сировинного забезпечення, а саме коефіцієнт оборотності матеріало-сировинних запасів. Як його лімінальне значення приймемо середньогалузеву величину в періоді оцінювання (L(Кобз)). Нестачу показника ЕВТ необхідно знаходити, коли лімінальне значення цього коефіцієнта перевищує нормативне (Кобзф), тобто коли виконується нерівність:

$$
\begin{gathered}
\mathrm{L}(\text { Кобз })>\text { Кобзф: } \\
\Delta \mathrm{EBT}(\text { Кобз })=\mathrm{EBT} \phi-\frac{\text { Кобзф }}{\mathbf{L}(\text { Кобз })} \times \mathrm{EBT} \phi,
\end{gathered}
$$

де $\triangle \mathrm{EBT}($ Кобз $)$ - нестача суми ЕВТ, визначена за коефіцієнтом оборотності матеріало-сировинних запасів підприємства, грн.

Загальна нестача показника EBT за безпекою матеріало-сировинного забезпечення підприємства ( $\triangle \mathrm{EBT}($ БМСЗ)) визначатиметься з виразу: 


$$
\begin{gathered}
\Delta \mathrm{EBT}(\text { БМС3 })=\max \{\Delta \mathrm{EBT}(\mathrm{Kmr}) ; \\
\Delta \mathrm{EBT}(\text { Кобз })\} .
\end{gathered}
$$

Отже, враховуючи сценарій найгіршого варіанту, загальну нестачу ЕВТ по безпеці економіко-виробничих інтересів ( $\triangle \mathrm{EBT}(\mathrm{БEBI))} \mathrm{знахо-}$ дитимемо як максимальне значення усіх нестач, отриманих за іiі складниками:

$$
\begin{gathered}
\Delta \mathrm{EBT}(\text { БЕВІ })=\max \{\Delta \mathrm{EBT}(\text { БТТІ }) ; \\
\Delta \mathrm{EBT}(\text { БЕнІ }) ; \Delta \mathrm{EBT}(\text { БМСІ }) .
\end{gathered}
$$

Отже, рівень безпеки (Р(БЕВІ)) пропонуємо визначати з виразу:

$$
\mathrm{P}(\text { БЕВІ })=1-\frac{\Delta \text { ЕВТ }(\text { БЕВІ })}{\mathrm{EВТ} \mathrm{(БЕВІ})},
$$

де ЕВТ(БЕВІ)л - лімінальна величина ЕВТ, яка $\epsilon$ сумою фактичного значення ЕВТ і його нестачі ( $\triangle \mathrm{EBT}($ БЕВI)), грн.

Відзначимо, що лімінальними величинами залежно від періоду оцінювання можуть бути не тільки середньогалузеві, як нами показано в роботі. Іноді актуалізується вибір як баз для порівняння (i, відповідно, лімінальних величин) найкращих значень серед підприємств-конкурентів. Останнє передбачає те, що залежно від економічного сенсу індикатора лімінальними можуть бути як максимальні, так і мінімальні його значення у певному проміжку часу.

Чим ближче до одиниці буде отримане значення $\mathrm{P}($ БЕВІ), тим вище рівень безпеки економіко-виробничих інтересів на підприємстві.

Висновки. Вдосконалена методологія оцінювання безпеки економіко-інформаційних інтересів підприємства, на відміну від наявних, грунтується на розширеному наборі індикаторів, які дають змогу адекватно оцінити нестачу ЕВT i надати більш обгрунтовані висновки щодо рівня цієї безпеки. Викладений концептуальний підхід передбачає прямий рахунок і досить прозоре інтегрування отриманих сум нестач EBT за всіма підвидами цієї безпеки, розташованими на різних рівнях іiі ієрархії. Це робить його зручним i результативним інструментом для прийняття управлінських рішень, спрямованих не тільки на забезпечення економічної безпеки, але й на підвищення ефективності виробничої діяльності підприємства загалом.

\section{Список використаних джерел:}

1. Нусінова О.В. Комплексна оцінка соціально-економічної безпеки підприємства (на прикладі підприємств гірничодобувної промисловості) : монографія. Кривий Ріг : Діоніс, 2011. 240 с.

2. Нусінова О.В. Оцінка фінансової безпеки підприємств : монографія. Кривий Ріг : Діоніс, 2011. 192 с.

3. Кашубіна Ю.Б., Міщук Є.В. Дефініції економічної категорії «інвестиційна безпека». Інвестиції: практика та досвід. 2015. № 2. С. 12-18.

4. Алькема В.Г., Больботенко І.В. Методика оцінки рівня економічної безпеки суб’єктів аудиторської діяльності. Глобальні та національні проблеми економіки. 2014. Вип. 2. С. 375-382.

5. Нусінов В.Я., Астаф'єва К.О., Нусінова О.В. Оцінка рівня економічної безпеки підприємства на всіх етапах розвитку : монографія. Кривий Ріг : Чернявський Д.О., 2015. 185 с.

6. Корецька О.В. Теоретичні підходи до управління фінансово-економічною безпекою підприємств портової галузі. Глобальні та національні проблеми економіки. 2017. Вип. 15. С. 225-229.

7. Дуб Б.С. Система економічної безпеки підприємства: поняття та структура. Управління проектами та розвиток виробництва. 2016. № 4 (60). С. 5-18.

8. Івченко Є.А. Трансформації системи економічної безпеки підприємства : монографія. Сєвєродонецьк : вид-во СНУ ім. В. Даля, 2018. 420 с.

9. Данілова Е.І. Ідентифікація об'єкта управління економічною безпекою підприємства. Вісник Житомирського державного технологічного університету. Серія: Економіка, управління та аддіністрування. 2019. № 1 (87). С. 139-144.

10. Меліхова Т.О. Модель створення системи економічної безпеки підприємства: економічна ефективність витрат у короткостроковому періоді. Вісник Кременчуиького національного університету імені Михайла Остроградського. 2018. Вип. 1 (108). С. 154-159.

11. Нусінов В.Я., Буркова Л.А., Нусінова О.В. Комплексна оцінка економічних результатів діяльності підприємств з урахуванням ступеня кризи їх фінансового стану : монографія. Кривий Ріг : Козлов Р.А., 2016. 228 c.

\section{References:}

1. Nusinova O.V., Molodec'ka O.M. (2011). Kompleksna ocinka social'no-ekonomichnoi' bezpeky pidpryjemstva (na prykladi pidpryjemstv girnychodobuvnoi' promyslovosti) [Comprehensive assessment of socio-economic security of the enterprise (for example, mining enterprises)], monografija, vyd-vo Dionis (FOP Chernjavs'kyj D.V.), $240 \mathrm{p}$.

2. Nusinova O.V. (2011). Ocinka finansovoi' bezpeky pidpryjemstv [Assessment of financial security of enterprises], monografija, vyd-vo Dionis, $192 \mathrm{p}$.

3. Kashubina Yu.B., Mishchuk I.V. (2015). Definiciï ekonomichnoï kategorii "investicijna bezpeka" [Definitions of the economic category "investment security"]. Investiciï: praktika ta dosvid: naukovo-prakt. Zhurnal, № 2, pp. 12-18.

4. Al'kema V.G., Bol'botenko, I.V. (2014). Metodyka ocinky rivnja ekonomichnoi' bezpeky sub'jektiv audytors'koi' dijal'nosti [Methods for assessing the level of economic security of audit entities]. Global'ni ta nacional'ni problemy ekonomiky. Vol. 2, pp. 375-382.

5. Nusinov V.Ya., Astaf'єva K.O., Nusinova O.V. Ocinka rivnya ekonomichnoï bezpeki pidpriemstva na vsih etapah rozvitku [Assessment of the level of economic security of the enterprise at all stages of development], monografiya, Krivij Rig : Chernyavs'kij D.O., 2015, 185 p. 
6. Koretskaya O.V. (2017), Teoretichni pidhodi do upravlinnya finansovo-ekonomichnoyu bezpekoyu pidpriєmstv portovoï galuzi [Theoretical approaches to the management of financial and economic security of port industry enterprises]. Global'ni ta nacional'ni problemy ekonomiky, vol. 15, pp. 225-229.

7. Dub B.S.(2016), Sistema ekonomichnoï bezpeki pidpriemstva: ponyattya ta struktura [Enterprise economic security system: concept and structure]. Upravlinnia proektamy ta rozvytok vyrobnytstva, vol. 4 (60), pp. 5-18.

8. Ivchenko Je.A. (2018), Transformacii' systemy ekonomichnoi' bezpeky pidpryjemstva [Transformations of enterprise economic security system], monografija, vyd-vo SNU im. V. Dalja, Sjevjerodonec'k, 420 p.

9. Danilova E.I. (2019), Identyfikacija ob'jekta upravlinnja ekonomichnoju bezpekoju pidpryjemstva [Identification of the object of economic security management of the enterprise]. Visnyk Zhytomyrs'kogo derzhavnogo tehnologichnogo universytetu. No. 1 (87), pp. 139-144.

10. Melihova, T.O. (2018), Model' stvorennja systemy ekonomichnoi' bezpeky pidpryjemstva: ekonomichna efektyvnist' vytrat $\mathrm{u}$ korotkostrokovomu periodi [Model of creation of the enterprise economic security system: cost-effectiveness of costs in the short term]. Visnyk Kremenchuc'kogo nacional'nogo universytetu imeni Myhajla Ostrograds'kogo, vol. 1 (108), pp. $154-159$.

11. Nusinov, V.Ya., Burkova L.A., Nusinova O.V. (2016) Kompleksna otsinka ekonomichnykh rezul'tativ diyal'nosti pidpryyemstv z urakhuvannyam stupenya kryzy yikh finansovoho stanu : monohrafiya [Comprehensive assessment of economic performance of enterprises with regard to the degree of crisis of their financial condition: a monograph]. Kryvyy Rih : Kozlov R.A., 2016. $228 \mathrm{~s}$.

Mishchuk Ievgeniia

Kryvyi Rih National University

\section{METHODOLOGY FOR ASSESSING THE SAFETY LEVEL OF ECONOMIC AND PRODUCTION INTERESTS OF THE ENTERPRISE}

It was revealed that the approach to assessing the safety level of the economic and production interests of the enterprise, which would be based on the determination of a single-valued indicator for all its components, has remained insufficiently developed. It has been determined that as such an indicator it is advisable to assess the amount of the shortfall in profit before tax (EBT) that the company receives if the relevant safety indicators do not achieve their fixed values. The proposed conceptual approach was developed taking into account the differentiation in the security structure of economic and production interests of such components as: the safety of technical and technological interests, the safety of energy interests and the safety of material and raw material interests of the enterprise. The listed components, in turn, are also divided into separate subspecies. The basis of this division is the principle of the enterprise's need for the security of providing the necessary resources and the security of their efficient use. A fundamentally new approach, which allows assessing the level of security of security at a higher level, is to take into account the influence of the coefficients of correspondence of actual volumes of supply of resources (energy and raw materials) in monetary terms to the volumes declared in the concluded contracts on the amount of shortage of EBT. The improved methodology provides a direct account and a fairly transparent integration of the sums of shortcomings of the EBT obtained for all subspecies of this security, located at different levels of its hierarchy by the worst-case method: evaluating each next type of security located at a higher level of the hierarchy of security of economic and production interests, it is envisaged to select the maximum the magnitude of the lack of EBT. It is shown that in some cases, the resulting amount of shortage of EBT must be reduced by the amount associated with obtaining additional profit from the sale of assets not involved in the main production. This makes it a convenient and effective tool for making managerial decisions aimed not only at ensuring economic security, but also generally improving the efficiency of the enterprise's production activities.

Key words: safety of energy interests, safety of material and raw material interests, safety of technical and technological interests, profit.

JEL classification: D81, E23, L69. 